J. Reprod. Fert. (1967) 13, 169-171

BRIEF COMMUNICATION

\title{
HYSTERECTOMY AND HYPOPHYSIAL FSH AND LH LEVELS IN THE RAT
}

\author{
ANANT P. LABHSETWAR \\ Department of Anatomy, Washington University School of Medicini, \\ St Louis, Missouri, U.S.A.
}

(Received 23rd July 1966, revised 12th September 1966)

\begin{abstract}
Summary. Hypophysial levels of FSH (HCG augmentation method) and LH (ovarian ascorbic acid depletion method) were compared in pseudopregnant and in pseudopregnant-hysterectomized rats on Days 7 and 8 of pseudopregnancy. Hysterectomy failed to affect significantly the hypophysial levels of both gonadotrophins during the period studied.
\end{abstract}

Hysterectomy results in increased pituitary levels of follicle stimulating hormone (FSH) and luteinizing hormone (LH) in the pig (Parlow, Anderson \& Melampy, 1964) but not in the sheep (Collins, Inskeep, Howland, Pope \& Cadisa, 1966). In the rat, although the removal of the uterus results in a prolongation of pseudopregnancy, its effects on the pituitary levels of (FSH) and ( $\mathrm{LH})$ are unknown. Silbiger \& Rothchild (1963) reported a decrease in mouse uterine weight-stimulating activity in pituitary glands from hysterectomized rats and attributed the prolongation of pseudopregnancy to a decrease in gonadotrophin secretion from the pituitary resulting in its decreased luteolytic effectiveness. In the present study this hypothesis was tested by comparing the pituitary levels of FSH and LH in intact and hysterectomized pseudopregnant rats at Days 7 and 8 of pseudopregnancy using specific bio-assays. Silbiger \& Rothchild (1963) stated that the difference between intact and hysterectomized rats in the total gonadotrophin content of the pituitary becomes discernible by Day 7 of pseudopregnancy, and Schwartz \& Rothchild (1964) have found that a significant increase in pituitary LH stores has occurred by this day.

Adult female rats of Holtzman strain were hysterectomized as described by Perry \& Rowlands (1961). Pseudopregnancy in these and in intact animals was induced by electrical stimulation on the day of oestrus and/or pro-oestrus. Pseudopregnancy was judged by daily vaginal smears. The animals were killed on Day 7 or 8 of pseudopregnancy (presence of leucocytes in the vaginal smear following electrical stimulation considered Day 1), and the weights of ovaries and pituitaries were recorded. The pituitary glands of two rats in each group were pooled to obtain three pools per group and assayed for FsH by a modification of the HCG augmentation test (Steelman \& Pohley, 1953). The 
pituitary material was injected in combination with 20 i.u. of HCG into 26-dayold Holtzman female rats twice daily for 3 days. Two doses of the reference standard and one dose of pituitary suspension from each experimental group were assayed simultaneously. The remaining pituitary material was pooled within each group and assayed for $\mathrm{LH}$ by the ovarian ascorbic acid depletion method of Parlow (1961) using a modification which employed two ovaries and a 3-hr \pm 10 -min interval between the intravenous injection of the test material and autopsy. A symmetrical $2+2$ assay design with a minimum of four rats per dose level was used. Relative potency, confidence limits and index of precision $(\lambda)$ were calculated by the method described by Gaddum (1953) for parallel line assays.

The results show that the removal of the uterus did not affect significantly the pituitary or ovarian weights, or the pituitary FSH and LH levels (Table 1). These results are in contrast with those reported by Silbiger \& Rothchild

TABLE 1

FSH AND LH LEVELS IN PITUITARIES OF INTACT AND HYSTEREGTOMIZED PSEUDOPREGNANT RATS

\begin{tabular}{|c|c|c|}
\hline & $\begin{array}{c}\text { Intact, } \\
\text { pseudopregnant }\end{array}$ & $\begin{array}{c}\text { Hysterectomized, } \\
\text { pseudopregnant }\end{array}$ \\
\hline $\begin{array}{l}\text { No. of rats } \\
\text { Ovarian weight (mg/100 g) } \\
\text { Pituitary weight ( } \mathrm{mg} / 100 \mathrm{~g}) \\
\text { FsH } \dagger(\mu \mathrm{g} / \mathrm{mg} \text { wet pituitary) } \\
\text { LH } \ddagger \text { ( } \mu \mathrm{g} / \mathrm{mg} \text { wet pituitary) } \\
\text { Index of precision }(\lambda) \\
\quad \text { for LH assay }\end{array}$ & $\begin{array}{c}6 \\
28 \cdot 0 \pm 0.9 * \\
4-23 \pm 0.30 \\
4 \cdot 3 \pm 1 \cdot 1 \\
3 \cdot 3(0.7 \text { to } 5 \cdot 3) 5 \\
0.116\end{array}$ & $\begin{array}{c}6 \\
30 \cdot 4 \pm 1.0 \\
3 \cdot 88 \pm 0.13 \\
3.9 \pm 0.25 \\
2 \cdot 8(1.2 \text { to } 4 \cdot 7) \\
0.101\end{array}$ \\
\hline
\end{tabular}

* Mean \pm S.E.

$\dagger \mu \mathrm{g}$ equivalents of NIH-FSH-S-3 (ovine); mean based on assay of three pituitary pools.

$\ddagger \mu \mathrm{g}$ equivalent of NIH-LH-S-5 (ovine).

$\$ 95 \%$ confidence limits.

(1963). This apparent discrepancy may arise because: (i) the present data are too limited since only one stage of pseudopregnancy was studied, (ii) their method fails to differentiate between FSH and LH, and/or (iii) the assay of pituitaries from control and hysterectomized rats in their experiments was performed years apart and not simultaneously. The need for the latter is apparent since no reference standard was used.

I wish to sincerely thank Dr A. C. Enders for his interest and critical reading of the manuscript. This work was supported by United States National Science Foundation Grant GB-2476, and by Grant 5 T1 HD-21-04 from the National Institute of Child Health and Human Development. Appreciation is also extended to the Endocrine Study Section of the National Institutes of Health, United States Public Health Service, for liberal supplies of LH and FSH.

\section{REFERENCES}

Collins, W. E., Inskeep, E. K., Howland, B. E., Pope, A. L. \& Casida, L. E. (1966) Effects of hysterectomy and corpus luteum indication on pituitary-ovarian relationships in the ewe. 7 . Anim. Sci. 25, 87. 
Gaddum, J. H. (1953) Simplified mathematics for bioassays. F. Pharm. Pharmacol. 6, 345.

PARLow, A. F. (1961) Bioassay of pituitary luteinizing hormone by depletion of ovarian ascorbic acid. Human Pituitary Gonadotropins, p. 300. Ed. A. Albert. Thomas, Springfield.

Parlow, A. F., Anderson, L. L. \& Melampy, R. M. (1964) Pituitary follicle-stimulating hormone and luteinizing hormone concentrations in relation to reproductive stages of the pig. Endocrinology, 75, 365 .

Perry, J. S. \& Rowlands, I. W. (1961) Effect of hysterectomy on the ovarian cycle of the rat. $\mathcal{F}$. Reprod. Fert. 2, 332.

Schwartz, N. B. \& Rothchild, I. (1964) Changes in pituitary LH concentration during pseudopregnancy in the rat. Proc. Soc. exp. Biol. Med. 116, 107.

Silbiger, M. \& Rothchild, I. (1963) The influence of the uterus on the corpus luteum-pituitary relationship in the rat. Acta endocr., Copenh. 43, 521.

Steelman, S. L. \& Pohley, F. M. (1953) Assay of the follicle stimulating hormone based on the augmentation with human chorionic gonadotropin. Endocrinology, 53, 604. 